\title{
OPEN
}

\section{Author Correction: A ferroptosis- based panel of prognostic biomarkers for Amyotrophic Lateral Sclerosis}

\author{
David Devos $\mathbb{D}$, Caroline Moreau, Maeva Kyheng, Guillaume Garçon, Anne Sophie Rolland, \\ Hélène Blasco, Patrick Gelé, T. Timothée Lenglet, C. Veyrat-Durebex, Philippe Corcia,

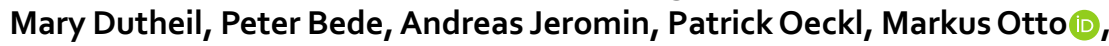 \\ Vincent Meininger, Véronique Danel-Brunaud, Jean-Christophe Devedjian, James A. Duce \& \\ Pierre François Pradat
}

Correction to: Scientific Reports https://doi.org/10.1038/s41598-019-39739-5, published online 27 February 2019

The original version of this Article contained a typographical error in the spelling of the author Vincent Meininger, which was incorrectly given as Vincent Meninger. This has now been corrected in the PDF and HTML versions of the Article, and in the accompanying Supplementary Information file.

(c) Open Access This article is licensed under a Creative Commons Attribution 4.0 International License, which permits use, sharing, adaptation, distribution and reproduction in any medium or format, as long as you give appropriate credit to the original author(s) and the source, provide a link to the Creative Commons license, and indicate if changes were made. The images or other third party material in this article are included in the article's Creative Commons license, unless indicated otherwise in a credit line to the material. If material is not included in the article's Creative Commons license and your intended use is not permitted by statutory regulation or exceeds the permitted use, you will need to obtain permission directly from the copyright holder. To view a copy of this license, visit http://creativecommons.org/licenses/by/4.0/.

(c) The Author(s) 2020 